\title{
Splenic artery pseudoaneurysm: learning from errors
}

\author{
Davood Farsi, Peyman Hafezimoghadam, Mohamad Amin Zare
}

Emergency Department, Tehran University of Medical Sciences, Tehran, Iran

Correspondence to Dr Peyman Hafezimoghadam, hafezimoghadam@yahoo.com

\section{DESCRIPTION}

Aneurysm refers to a pathologic dilatation in some sections of an artery. Splenic artery aneurysm is the most common of all splanchnic arterial aneurysms and comprise near $60 \%$ of such aneurysms. Diagnosis of splenic artery aneurysms is important because they have considerable tendency to rupture. ${ }^{1}$ We report a 55 -year-old man who presented to the emergency department (ED) with dizziness, malaise, and cold sweating and mild generalised abdominal discomfort. His symptoms started suddenly when he turned his head and upper trunk to see behind his car through the rear window. Except for a history of past trauma during a motor vehicle collision, which had resulted in fracture of left 5 th to 8 th ribs 5 years ago (figure 1), there was not other remarkable pertinent finding in his medical history. The patient was conscious and haemodynamically stable at triage; blood pressure: 120/80 mm Hg, pulse rate: $75 \mathrm{bpm}$ and respiratory rate: $16 / \mathrm{min}$. A presyncope investigation was initiated upon patient's arrival to the $\mathrm{ED}$, which included obtaining an ECG and a brain CT. Both tests were reported normal. The patient's vital signs remained stable, however, because of continuous abdominal discomfort, an abdominal ultrasound study was performed, which only revealed a $5 \mathrm{~cm}$ left renal cyst (figure 2). The patient was admitted to Emergency Observation Unit for repeat abdominal examination and observation. During his stay in this unit, he became hypotensive and tachycardic, and was found to have profuse sweating. A repeat bedside ultrasound study was performed, which revealed free fluid in abdominal cavity (in Morison pouch), in addition to the same renal cyst. At this point, the patient had significant abdominal tenderness and rebound tenderness. After infusion of crystalloids and Packed red blood cells, the patient was transferred to the operating room with suspicion of intra-abdominal haemorrhage. Immediately after anaesthesia induction, he developed cardiopulmonary arrest. Cardiopulmonary resuscitation was unsuccessful and the patient expired. Autopsy findings revealed splenic artery pseudoaneurysm rupture as the cause of death. History of trauma to left side of chest and abdomen could have been the cause of pseudoaneurysm formation in splenic artery. ${ }^{2}$ According to the literature, splenic artery aneurysm could present with unusual symptoms such as gastrointestinal

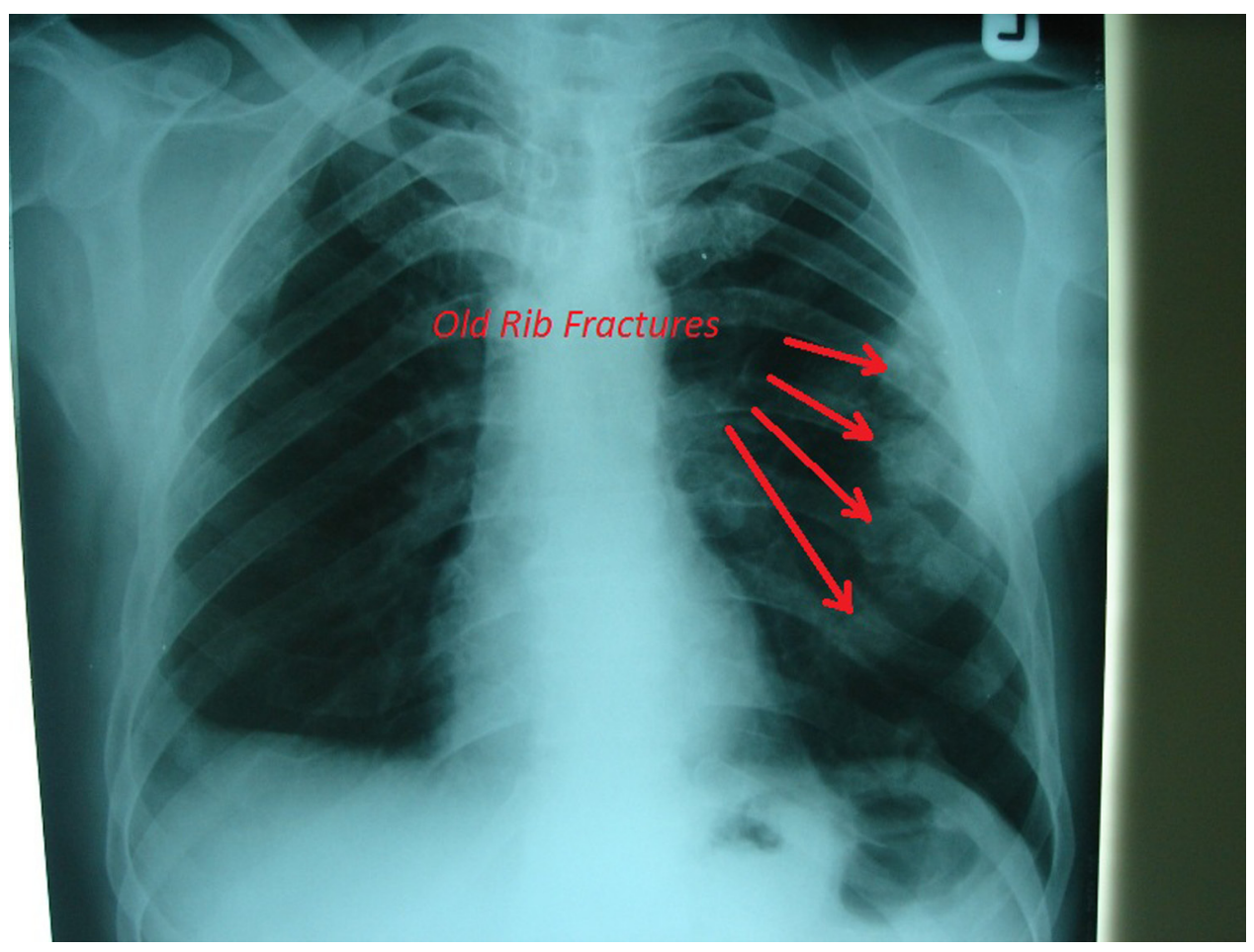

Figure 1 Chest x-ray showing old rib fractures in left hemithorax. 


\section{BMJ Case Reports}

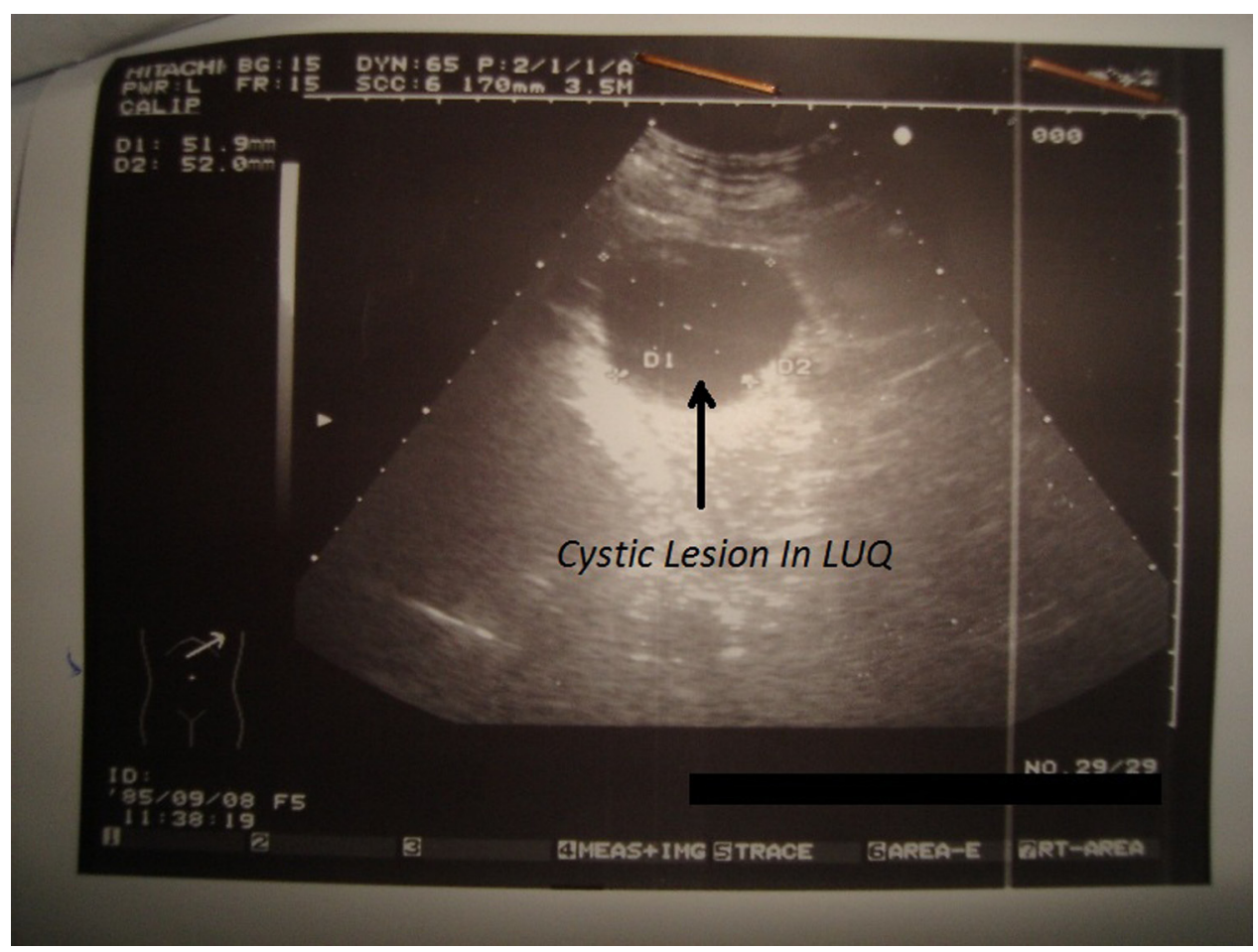

Figure 2 A view of sonography showing cystic lesion in left upper quadrant of abdomen. It had been reported as cyst in kidney but it was a splenic artery aneurysm.

bleeding or cardiopulmonary collapse after a brief epigastric pain. ${ }^{3}$

\section{Learning points}

- When the patient was presented with abdominal pain and symptoms relevant to decrease in intravascular volume such as dizziness or cold sweats, it is necessary to consider the possibility of intra-abdominal vascular catastrophe.

- Fluid responsive patients with hypovolemic shock state should be evaluated with standard diagnostic modalities to find the site of bleeding. (As in our case abdominal CT scan was necessary after initial response to fluid resuscitation)

- History of trauma to the chest or abdomen should raise the suspicion for splenic artery pseudoaneurysm.

- Ultrasonography is not sufficiently sensitive to differentiate benign cystic lesions such as renal cysts from pseudoaneurysms.
Competing interests None.

Patient consent Not obtained.

\section{REFERENCES}

1. Fauc AS, Braunwald E, Kaspe D. Harrison's Principle of Internal Medicine. 17th edn. Volume III. New York: McGraw-Hill Medical Publishing Division, 2008:1563.

2. Agrawal GA, Johnson PT, Fishman EK. Splenic artery aneurysm and pseudoaneurysms: clinical distinctions and CT appearance. Am J Roentgenol 2007;188:992-9.

3. Betal D, Khangura JS, Swan PJ, et al. Spontaneous ruptured splenic artery aneurysm: a case report. Cases J 2009;2:7150. 


\section{BMJ Case Reports}

This pdf has been created automatically from the final edited text and images.

Copyright 2012 BMJ Publishing Group. All rights reserved. For permission to reuse any of this content visit http://group.bmj.com/group/rights-licensing/permissions.

BMJ Case Report Fellows may re-use this article for personal use and teaching without any further permission.

Please cite this article as follows (you will need to access the article online to obtain the date of publication).

Farsi D, Hafezimoghadam P, Zare MA. Splenic artery pseudoaneurysm: learning from errors. BMJ Case Reports 2012;10.1136/bcr.10.2011.4903, Published XXX

Become a Fellow of BMJ Case Reports today and you can:

- Submit as many cases as you like

- Enjoy fast sympathetic peer review and rapid publication of accepted articles

- Access all the published articles

- Re-use any of the published material for personal use and teaching without further permission

For information on Institutional Fellowships contact consortiasales@bmjgroup.com

Visit casereports.bmj.com for more articles like this and to become a Fellow

Keep up to date with all published cases by signing up for an alert (all we need is your email address) http://casereports.bmj.com/cgi/alerts/etoc 